\title{
Control of Food Intake by Gastrointestinal Peptides: Mechanisms of Action and Possible Modulation in the Treatment of Obesity
}

\author{
Philip Prinz and Andreas Stengel* \\ Charité Center for Internal Medicine and Dermatology, Department for Psychosomatic Medicine, Charité-Universitätsmedizin Berlin, Berlin, \\ Germany
}

This review focuses on the control of appetite by food intake-regulatory peptides secreted from the gastrointestinal tract, namely cholecystokinin, glucagon-like peptide 1, peptide YY, ghrelin, and the recently discovered nesfatin-1 via the gut-brain axis. Additionally, we describe the impact of external factors such as intake of different nutrients or stress on the secretion of gastrointestinal peptides. Finally, we highlight possible conservative - physical activity and pharmacotherapy-treatment strategies for obesity as well as surgical techniques such as deep brain stimulation and bariatric surgery also altering these peptidergic pathways.

(J Neurogastroenterol Motil 2017;23:180-196)

\section{Key Words}

Bariatric surgery; Brain-gut axis; Deep brain stimulation; Psychosomatic; Obesity

\section{Introduction}

The control of food intake is well balanced in healthy individuals with mostly peptidergic regulators stimulating the feeling of hunger to initiate food intake or satiety to terminate food intake when the necessary amount of externally delivered energy is reached. A dysregulation of this system can lead to obesity. ${ }^{1}$ For a better understanding of the control of food intake it is necessary to understand the interaction of peripheral and central signals that regulate energy homeostasis. Briefly, several peptides are derived from the gastrointestinal tract, most of which inhibit food intake, namely cholecystokinin (CCK), glucagon-like peptide 1 (GLP-1), peptide tyrosine tyrosine (PYY), and the recently discovered nesfatin- $1,{ }^{3}$ while only one peripherally produced and centrally acting peptide is known to stimulate food intake, ghrelin. ${ }^{2}$ These peptides affect brain centers involved in the central control of hunger and satiety via the gut-brain axis that involves crossing of the blood-brain barrier and targeting the arcuate nucleus (ARC) of the hypothalamus, or an action via the vagus nerve to reach the nucleus of the solitary tract (NTS) of the brainstem. ${ }^{4}$ It is of note that these 2 pathways are not separated from each other but rather intertwined by neuronal networks; ie, the NTS and the paraventricular nucleus (PVN) of the hypothalamus are connected by nerve fibers.

When anorexigenic signals reach the ARC they activate proopiomelanocortin (POMC)- and cocaine- and amphetamine-related

Received: November 8, 2016 Revised: None Accepted: December 6, 2016

@) This is an Open Access article distributed under the terms of the Creative Commons Attribution Non-Commercial License (http://creativecommons. org/licenses/by-nc/4.0) which permits unrestricted non-commercial use, distribution, and reproduction in any medium, provided the original work is properly cited.

*Correspondence: Andreas Stengel, MD, PhD Department for Psychosomatic Medicine, Charité-Universitätsmedizin Berlin, Campus Benjamin Franklin, Hindenburgdamm 30, 12203 Berlin, Germany

Tel: +49-30-450-553-002, E-mail: andreas.stengel@charite.de 
transcript- (CART) containing neurons, and deactivate neuropeptide Y (NPY)- and Agouti-related peptide (AgRP)- containing neurons. ${ }^{4}$ POMC/CART leads to an activation of melanocortin receptors 3 and 4 in the PVN and the lateral hypothalamic area (LHA), which causes a reduction of food intake. ${ }^{4}$ The melanocortin receptor 4 is expressed in the NTS as well, which also contains POMC neurons. In contrast, ghrelin as an orexigenic peptide activates NPY/AgRP-containing neurons and deactivates POMC/ CART-containing neurons in the ARC. ${ }^{5}$ NPY stimulates food intake by activating the $\mathrm{Y}_{1}$ receptor in the PVN, whereas AgRP increases food intake as an antagonist of the melanocortin receptor 3 and $4 .^{5}$ Additionally, NPY can also act in the NTS to stimulate food intake. Taken together, peripheral and central signals are involved in the orchestration of food intake. While peripheral transmitters reach the brain via the blood-brain barrier or the vagus nerve and modulate brain neuronal activity, brain nuclei also release peptidergic transmitters such as oxytocin or corticotropin-releasing factor that affect peripheral binding sites eg, at the level of the enteric nervous system to modulate food intake. ${ }^{4,5}$

In the present review, we focus on gastrointestinal peptides mainly involved in the regulation of hunger and satiety. In comparison to other excellent reviews on gut peptides with a main focus on the reward system, ${ }^{6,7}$ pharmacological treatment, ${ }^{6,8}$ bariatric surgery ${ }^{9}$ or the gut microbiota, ${ }^{10}$ in the present review we comprehensively describe the main effects and routes of peptide signaling, the regulation by nutrients, and also external stressors increasingly recognized to affect gastrointestinal peptides. Lastly, we highlight strategies to modulate peptidergic signaling in the treatment of obesity: here, conservative (physical activity and pharmacological treatment) as well as surgical options will be highlighted (bariatric surgery and the rather novel method of deep brain stimulation).

\section{Gastrointestinal Hormones Regulating Hunger and Satiety}

\section{Ghrelin}

Ghrelin stimulates food intake after central and peripheral administration and subsequently also increases body weight. ${ }^{11}$ These effects are blunted after vagotomy pointing towards this route of gut-brain signaling. ${ }^{12}$ However, ghrelin can also pass the bloodbrain barrier bidirectionally. ${ }^{13}$ The main source of circulating ghrelin is the stomach, as indicated by a massive reduction of circulating ghrelin levels following gastrectomy. ${ }^{14}$ Ghrelin is produced in gastric endocrine $\mathrm{X} / \mathrm{A}$-like cells (in humans termed $\mathrm{P} / \mathrm{D}_{1}$ cells) ${ }^{15}$ and requires an acylation on its third serin residue necessary for the binding to and activation of the ghrelin receptor, the growth hormone secretagogue receptor 1a (GHSR1a, today often also called ghrelin receptor). ${ }^{16}$ The enzyme that catalyzes this acylation is the ghrelin- $O$ acyltransferase (GOAT), ${ }^{17,18}$ also expressed in the X/Alike cells of rodents ${ }^{19}$ and $\mathrm{P} / \mathrm{D}_{1}$ cells of humans. ${ }^{20}$ It is important to note that GOAT was also detected in the circulation of rodents ${ }^{19}$ and humans ${ }^{21}$ giving rise to a possible extragastric acylation of ghrelin.

Besides the direct effect after central injection, ghrelin also increases food intake following intraperitoneal administration in rats ${ }^{22}$ and intravenous infusion in humans ${ }^{23}$ likely reaching the hindbrain via the vagus nerve (or directly, since it is known that the NTS expresses the GHSRla in humans), ${ }^{24}$ and the ARC also expressing the GHSR $1 a^{25}$ via crossing the blood-brain barrier. In the ARC the GHSR1a is co-localized in neurons expressing NPY/AgRP ${ }^{26}$ and ghrelin increases NPY/AgRP activity, while POMC is inhibited. ${ }^{27}$ In NPY/AgRP knockout (KO) mice ghrelin failed to increase food intake pointing towards the important role of NPY/AgRP to mediate ghrelin's orexigenic effect. ${ }^{28}$ In addition to ghrelin's food intakestimulatory effects, peripherally injected ghrelin increases abdominal white adipose tissue in rodents. ${ }^{29}$ Ghrelin is also involved in the regulation of thermogenesis in brown adipose tissue with GHSR1a $\mathrm{KO}$ mice showing an increased thermogenesis in brown adipose tissue giving rise to an energy expenditure-reducing effect of ghrelin. ${ }^{30}$ Moreover, ghrelin stimulates gastric acid secretion as well as gastric motility in rats ${ }^{31}$ and humans, ${ }^{32}$ while often supraphysiological doses are needed in order to enhance motility. ${ }^{31}$ Both effects are blunted by cervical vagotomy indicating a vagal mediation. ${ }^{31}$ Lastly, ghrelin is also involved in glucose homeostasis with a decrease of insulin secretion following intravenous administration of ghrelin, while insulin sensitivity was not altered in humans. ${ }^{33}$

Over the last years, there has been increasing knowledge on desacyl ghrelin, the major circulating form of ghrelin ${ }^{34}$ that for long was thought to be an inactive deactivation product of ghrelin without any endogenous activity due to the lack of binding to the GHSR 1a. ${ }^{16}$ However, desacyl ghrelin might also play a role in the modulation of hunger and satiety based on the finding that coinjection of desacyl ghrelin and ghrelin greatly blunts the orexigenic effect of ghrelin in rats. ${ }^{35}$ In line with this finding, a recent study showed that desacyl ghrelin antagonizes the orexigenic effect of peripherally administered ghrelin in mice. ${ }^{36}$ This points towards a counteracting function of desacyl ghrelin to modulate/balance ghrelin's food intake-stimulating effect. This antagonism was also observed on colorectal motility: desacyl ghrelin reduced the motility- 
stimulating effect of ghrelin after intrathecal co-injection in rats. ${ }^{37}$ This interesting interplay of ghrelin and desacyl ghrelin warrants further investigation; moreover, the receptor mediating desacyl ghrelin's effects is yet to be identified.

\section{Nesfatin-1}

Nesfatin-1 is a recently discovered peptide derived from the precursor protein nucleobindin2 (NUCB2) and was initially described to be expressed in the rat hypothalamus. ${ }^{38}$ Early on it was shown that nesfatin-1 reduces food intake following central injection in rats, ${ }^{38,39}$ mice ${ }^{40}$ or goldfish. ${ }^{41}$ Subsequent research showed a more widespread distribution of NUCB2/nesfatin-1 in the rat brain ${ }^{42}$ and a prominent expression in the rat stomach with 10 -fold higher expression levels in the gastric oxyntic mucosa compared to the brain. ${ }^{43}$ It is important to note that nesfatin-1 was co-localized with ghrelin in gastric $\mathrm{X} / \mathrm{A}$-like cells in rats ${ }^{43}$ and $\mathrm{P} / \mathrm{D}_{1}$ cells in humans ${ }^{20}$ leading to the hypothesis that the peptide products of the X/A-like cell can stimulate food intake in both directions: either stimulate via ghrelin or inhibit via nesfatin-1.

Peripherally injected nesfatin-1 activates the NTS as indicated by increased Fos expression which might be involved in the satiety signaling. ${ }^{44}$ Moreover, nesfatin-1 can cross the blood-brain barrier bidirectionally in a non-saturable manner ${ }^{45,46}$ possibly leading to an activation of food intake-regulatory nuclei such as the PVN of the hypothalamus, a nucleus recently suggested to express the yet unknown nesfatin-1 receptor in a study using autoradiography. ${ }^{47}$ However, it is of note that although one study reported a reduction of food intake following intraperitoneal injection of nesfatin-1 at high doses in mice, ${ }^{44}$ other studies in rats ${ }^{39}$ or mice ${ }^{40}$ were unable to show this anorexigenic action of peripheral nesfatin-1. Also chronic peripheral administration of the peptide provided inconsistent results: while a reduction of food intake was observed in rats, ${ }^{48}$ no effects were described in mice. ${ }^{49}$ Whether species differences play a role remains to be further investigated. In summary, current data clearly point towards a role of central nesfatin- 1 in the regulation of food intake, whereas peripheral nesfatin-1 seems to be rather involved in the reduction of gastric motility in dogs,${ }^{50}$ increase of hepatic $\beta$-oxidation ${ }^{49}$ and glucose homeostasis with an increase of glucose-stimulated insulin release from the pancreas in rats ${ }^{51}$ and humans. ${ }^{52}$

\section{Cholecystokinin}

Cholecystokinin (CCK) is mainly secreted from I cells of the upper small intestine $;^{53}$ however, expression has also been detected in the enteric nervous system encompassing the myenteric and submucosal plexus. ${ }^{54}$ Various forms of CCK were detected since its discovery (CCK-5, $-7,-8,-18,-22,-25,-33,-39,-58$, or posttranslationally sulphated forms), while only CCK- 8 and CCK- 58 have been observed in the central nervous system. ${ }^{53}$ The anorexigenic effect of CCK was discovered in 1973 in rats ${ }^{55}$ and confirmed in different species including rabbits, monkeys, pigs, sheep and humans. ${ }^{53}$ CCK-8 is the most studied form; however, when blood processing was optimized and degradation inhibited using the RAPID method, only CCK-58 was detectable suggesting that the shorter CCK forms represent fragments derived from enzymatic degradation. ${ }^{56}$ Although both forms reduce dark phase food intake following intraperitoneal injection in rats, CCK- 58 exerts a different effect on the underlying food intake microstructure with a reduction of meal size, while the inter-meal interval following this meal was not shortened, a finding observed after injection of CCK- $8{ }^{57}$

Originally, CCK was described as a stimulator of gallbladder contraction, pancreatic secretion, and synthesis of pancreatic enzymes as well as a modulator of gastric motility. ${ }^{53}$ Part of these actions are different between species with CCK being an inhibitor of gastric motility in humans ${ }^{58}$ and rats ${ }^{59}$ and a stimulator in guinea pigs. ${ }^{60} \mathrm{CCK}$ 's actions are mediated by binding to $2 \mathrm{G}$ protein-coupled receptors, the $\mathrm{CCK}_{\mathrm{A}}$ and $\mathrm{CCK}_{\mathrm{B}}$ receptors. $\mathrm{CCK}_{\mathrm{A}}$ (alimentary) is expressed in several tissues including the gastrointestinal tract, liver, pancreas and on vagal afferents, ${ }^{53}$ whereas the $\mathrm{CCK}_{\mathrm{B}}$ (brain) is the predominant form in the central nervous system. ${ }^{61}$

In addition to the functions described above $\mathrm{CCK}$ reduces food intake. ${ }^{57,62}$ The peptide is released from intestinal I cells after food intake with the most potent stimulation by lipids and proteins, ${ }^{63,64}$ binds to the $\mathrm{CCK}_{\mathrm{A}}$ on vagal afferents and leads to an activation of cells in the NTS that ultimately induce a reduction of food intake. ${ }^{65,66}$ In humans, stimulation of the $\mathrm{CCK}_{\mathrm{A}}$ with the orally-active $\mathrm{CCK}_{\mathrm{A}}$ agonist, GI181771X did not induce a reduction of body weight, while gastrointestinal side effects and effects on gallbladder and bile duct were observed. ${ }^{67}$ Therefore, $\mathrm{CCK}_{\mathrm{A}}$ monotherapy does not seem to be a promising anti-obesity strategy. While other feeding-regulatory peptides affect food intake by crossing the blood-brain barrier, for CCK vagal mediation is the predominant pathway. ${ }^{68}$ This is further underlined by the finding that CCK's anorexigenic actions are attenuated by capsaicin treatment ${ }^{68,69}$ or blocked by abdominal vagotomy. ${ }^{66}$

\section{Glucagon-like Peptide 1}

Glucagon-like peptide 1 (GLP-1) is best known for its incretin effect with analogs used in the treatment of type 2 diabetes mellitus. $^{70}$ The most famous analogs of GLP-1 are exendin-4 and 
liraglutide that also reduce food intake in animals ${ }^{71}$ and humans. ${ }^{72,73}$ Therefore, besides its incretin effects, GLP-1 mimetics are promising targets in the treatment of obesity. ${ }^{70}$ GLP-1 is produced in endocrine $\mathrm{L}$ cells of the intestine and posttranslationally cleaved from the gene encoding proglucagon in its 2 biologically active forms, GLP- $1_{7-36}$ amide and GLP- $1_{7-37}{ }^{74}$ In humans, the major circulating form is the GLP-1 ${ }_{7-36}$ amide. $^{75}$ GLP-1 is released postprandially and directly after stimulation by nutrients or indirectly via other gastrointestinal hormones, such as gastric-inhibitory peptide ${ }^{76}$ or gastrin-releasing peptide ${ }^{77}$ or via the vagus nerve. ${ }^{78}$ The early peak of GLP-1 secretion occurs shortly after meal ingestion (approximately after 15 minutes) and involves an indirect hormonal/neuronal loop, ${ }^{78}$ whereas the second and larger peak appears later and is thought to be derived from direct contact of nutrients with $\mathrm{L}$ cells. ${ }^{70}$ This results in a reduction of food intake in animals ${ }^{79,80}$ and humans, ${ }^{81}$ which can be exerted at a peripheral ${ }^{81}$ as well as at a central level. ${ }^{79}$ Moreover, GLP-1 has also been implicated in the modulation of gastrointestinal motility with a decrease in gastric emptying and intestinal motility observed in humans ${ }^{82,83}$ and rats. ${ }^{84,85}$

Besides its expression in the gastrointestinal tract, GLP-1 is also expressed in neurons of the NTS which project to the $\mathrm{PVN}^{86}$ and are activated by several factors that decrease food intake (bacterial components like lipopolysaccharide or hormones such as CCK, leptin or oxytocin). ${ }^{70}$ Furthermore, the GLP-1 receptor (GLP-1R) is expressed on vagal afferents ${ }^{87}$ and the peripheral satiety effect of GLP-1 is blocked by vagotomy. ${ }^{88}$ Taken together, these data point towards a mediation of GLP-1's food intake-reducing effect by the vagus nerve and hindbrain circuits rather than crossing the blood-brain barrier. This is further supported by lesion experiments showing that disruption of the projections from the brainstem to the hypothalamus reduce the appetite-suppressing effect of peripherally injected GLP-1 in rats. ${ }^{88}$ Moreover, peripheral as well as central injection of GLP-1 induces Fos, a marker for neuronal activity, in the PVN, while only central injection of GLP-1 induces Fos in the ARC. ${ }^{89}$ Furthermore, knockdown of the proglucagon gene in the NTS results in an increase of food intake and body weight gain. ${ }^{90}$ Lastly, microinjection of GLP-1 into the ARC affected glucose metabolism and insulin release, whereas food intake was only affected by injection of GLP-1 into the PVN. ${ }^{91}$ This points towards a mediation of the peripheral anorexigenic GLP-1 effect by activation of vagal afferents and a subsequent hindbrain (NTS) to forebrain (PVN) signaling.

However, GLP-1 has also been shown to cross the bloodbrain barrier by simple diffusion ${ }^{92}$ and the GLP-1R is expressed in the hypothalamus as well. ${ }^{93}$ In line with this expression, peripheral injection of liraglutide was shown to directly stimulate POMC/ CART-containing neurons and to inhibit NPY/AgRP-containing neurons in the ARC resulting in a decrease of body weight. ${ }^{94}$ However, it is of note that after reaching the circulation endogenous GLP-1 is rapidly degraded by the enzyme dipeptidyl peptidase IV. ${ }^{95}$ Therefore, the vagal signaling pathway following paracrine receptor activation is likely to predominate.

A recent study in Sprague Dawley rats showed that knockdown of the GLP-1R in vagal afferents affects food intake by increasing meal size and meal duration, whereas the number of meals was reduced and overall food intake not altered compared to controls. ${ }^{96}$ Whether all these changes encompass GLP-1's effects or reflect compensatory mechanisms will have to be further investigated.

\section{Peptide YY}

Two native forms of human PYY are known, $\mathrm{PYY}_{1-36}$ and $\mathrm{PYY}_{3-36}$, with $\mathrm{PYY}_{3-36}$ (hereafter termed as PYY) being the major circulating form resulting from cleavage of $\mathrm{PYY}_{1-36}$ by DPP IV. ${ }^{97,98}$ PYY is primarily produced in $\mathrm{L}$ cells of the small intestine but also the colon. ${ }^{97}$ It is important to note that it took 20 years following its discovery in the porcine intestine ${ }^{99}$ to identify PYY as a peripheral inhibitory regulator of food intake postprandially acting via the $\mathrm{Y}_{2}$ receptor in the central nervous system, ${ }^{100}$ an effect blunted by central injection of the $\mathrm{Y}_{2}$ antagonist, BIIE0246. ${ }^{101}$ Microinjection of PYY into the ARC inhibited electrical activation of NPY-containing nerve terminals and activated adjacent POMC-containing neurons. ${ }^{100}$ Taken together, these results give rise to PYY as a peripheral and central regulator of food intake in animals ${ }^{100,102}$ and humans. $^{102}$

Interestingly, $\mathrm{Y}_{2}$ are localized on NPY-containing neurons in the ARC suggesting a direct action of PYY on hypothalamic neurons. ${ }^{103}$ This hypothesis is supported by the finding that peripheral PYY can cross the blood-brain barrier by a non-saturable mechanism. ${ }^{104}$ However, current data also point towards a vagal route of PYY signaling since the food intake-reducing effect of PYY following intraperitoneal injection was blocked by vagotomy in rats. ${ }^{105}$ Moreover, vagotomy also greatly decreased the PYY-induced expression of Fos in the ARC. ${ }^{105}$ Therefore, peripheral PYY is likely to signal to the brain both via the vagus nerve and via direct interaction with hypothalamic nuclei after crossing the blood-brain barrier. The peptidergic regulation of hunger and satiety is summarized in Figure 1. 


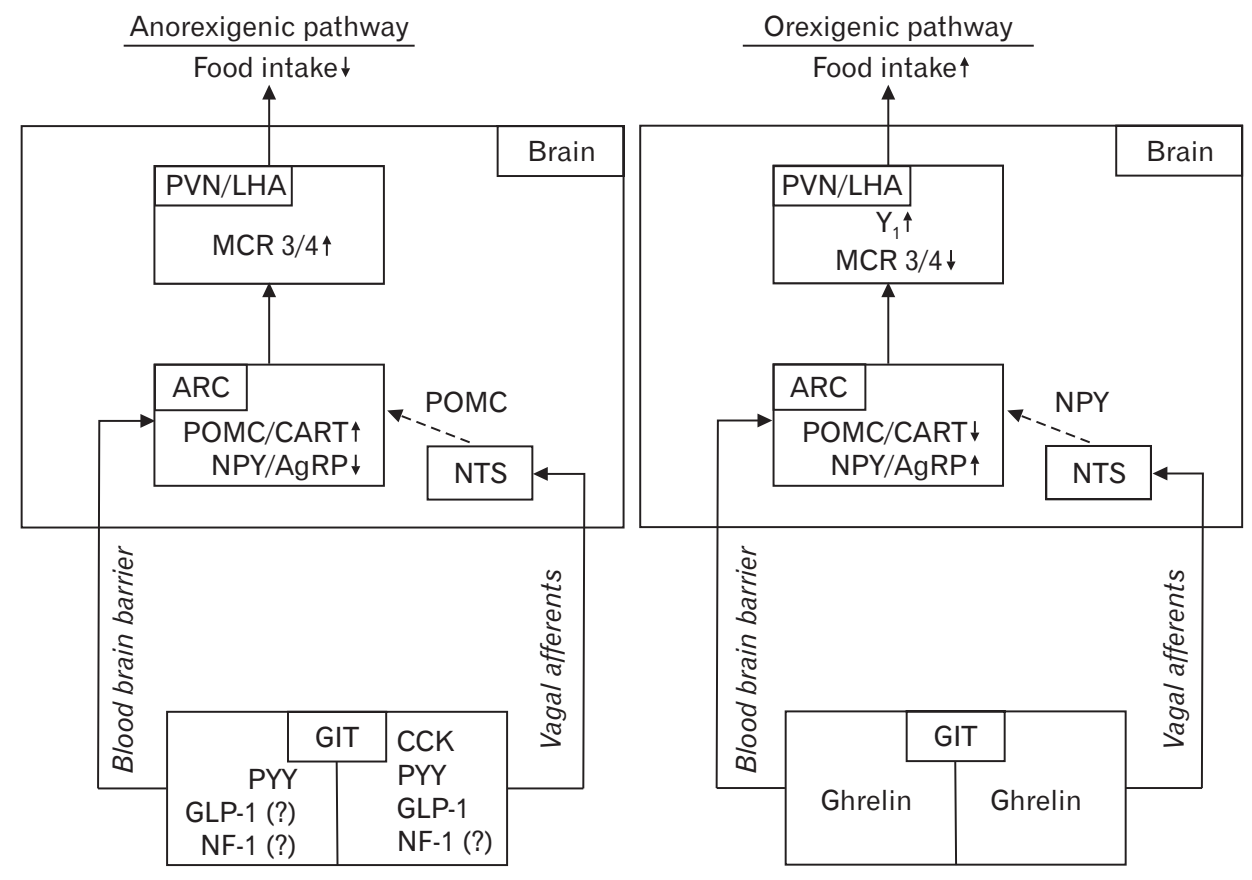

Figure 1. Effects of gastrointestinal peptides on food intake via the gut-brain axis. The left side shows the anorexigenic signaling pathway, whereas orexigenic signaling is shown on the right panel. PVN, paraventricular nucleus; LHA, lateral hypothalamic area; MCR 3/4, melanocortin receptors 3 and 4; ARC, arcuate nucleus; POMC, pro-opiomelanocortin; CART, cocaine-and amphetamine-regulatory transcript; NPY, neuropeptide Y; AgRP, agouti-related peptide; NTS, nucleus of the solitary tract; $\mathrm{Y}_{1}$, NPY receptor 1; GIT, gastrointestinal tract; PYY, peptide tyrosine tyrosine; GLP-1, glucagonlike peptide 1; NF-1, nesfatin-1; CCK, cholecystokinin; $\downarrow$, decrease; $\uparrow$, increase; ?, controversial data (NF-1) or data that resulted from mimetics (GLP-1).

\section{Influence of Nutrients and Stress on Peptidergic Regulators of Food Intake}

\section{Effects of Nutrients on Food Intake-modulating Hormones}

The release of gastrointestinal food intake-regulating peptides is greatly affected by ingested nutrients. The early release of CCK has been well described when nutrients reach the duodenum, while GLP-1 and PYY are released later when nutrients further proceed through the intestine. ${ }^{106}$ This points towards a direct contact of nutrients with enteroendocrine cells to trigger the release of anorexigenic peptides. ${ }^{106} \mathrm{CCK}$ is mainly stimulated by digested lipids and proteins, ${ }^{107,108}$ while intraduodenal glucose load exerted only a small increase of circulating CCK in healthy subjects. ${ }^{109}$ Further investigation of lipids and proteins showed that especially fatty acids with more than 12 carbons (oleate) or non-hydrolyzed and partially hydrolyzed proteins (casein or soybean trypsin inhibitors) stimulate $\mathrm{CCK}$ release. ${ }^{110} \mathrm{~A}$ number of $\mathrm{G}$ protein-coupled receptors has been described that can sense oral lipids in the gastrointestinal tract including FFAR1, PPR120 or GPR119 or a G protein-coupled receptor for bile acids, GPBAR1. A recent study showed that lipid superfusion on human duodenal biopsies increased GPR119 expression but not FFAR1 or FFAR4 and stimulated the secretion of CCK and GLP-1. ${ }^{111}$ Therefore, these receptors might be localized on the surface of I and L cells to trigger CCK and GLP-1 release following lipid sensing.

In contrast to CCK, GLP-1 is mainly triggered by glucose, ${ }^{109,112}$ which is sensed by the same sweet taste receptors on GLP-1-expressing L cells that are also expressed on the tongue, namely T1R2 and T1R3. ${ }^{113}$ Apart from the nutrients, the amount of energy also seems to play a role in gastrointestinal peptide release. PYY levels were shown to increase in response to nutrients proportionally to the amount of calories ingested ${ }^{114}$ and to decrease during fasting. ${ }^{115}$

Moreover, oral administration of glucose, lipids, and proteins in male and female healthy subjects showed that levels of the orexigenic peptide ghrelin decreased after glucose and lipid meals, whereas proteins did not affect circulating ghrelin. ${ }^{116}$ Interestingly, desacyl ghrelin can be directly acylated by GOAT using medium chain fatty acids or medium chain triacylglycerols of ingested foods. ${ }^{117}$ In vitro studies of cultured stomach ghrelinoma cells (MGN3-1) showed that oleic acids increase the expression of orexigenic ghrelin and simultaneously decrease the expression of NUCB2 (the precursor protein of the anorexigenic peptide nesfatin-1) ${ }^{118}$ also expressed in gastric X/A-like cells. Interestingly, L-tryptophan increased both NUCB2 expression and nesfatin-1 release as well as ghrelin expression, while glucose only stimulated NUCB2 expression. ${ }^{118}$ Since both peptides are derived from the same cell, different downstream signaling is likely to mediate this differential regulation. This has to be further investigated in future studies. 


\section{Effects of Stress on Food Intake-regulating Hormones}

The impact of psychological diseases and stress on food intakeregulatory peptides is well investigated for ghrelin and also for nesfatin-1, whereas studies for CCK, GLP-1, and PYY mostly focused on the impact of these peptides on the development of psychological disorders or stress.

Besides its orexigenic effect, ghrelin (subcutaneously injected or endogenously increased under conditions of caloric restriction) was shown to induce anxiolytic and antidepressant behavior in mice. ${ }^{119}$ These effects are ghrelin-specific and mediated by the GHSR1a as GHSR1a KO mice do not display these behaviors following ghrelin injection. ${ }^{119}$ In line with these acute findings, Wistar Kyoto rats which show more anxious behavior than Sprague Dawley rats have 2-fold lower fasting ghrelin levels. ${ }^{120}$ Taken together, these data give rise to the assumption that ghrelin might have beneficial effects in disorders involving anxiety or depression.

Chronic social defeat stress, representing a model of depression, increased circulating ghrelin levels. ${ }^{119}$ In this model the upregulation of ghrelin seems to play an adaptive/counter-regulatory role as mice lacking the GHSR1a showed even greater social avoidance. ${ }^{119}$ In line with these results, previous studies showed that acute stress resulted in increased circulating levels of ghrelin in mice ${ }^{121}$ and rats. ${ }^{122}$ In humans the results are divergent. A cold pressor test (a physiological laboratory stressor) increased circulating ghrelin levels in overweight women with and without night eating ${ }^{123}$ and obese women with binge eating disorder, ${ }^{124}$ while another study did not detect a correlation of plasma ghrelin with perceived stress in overweight and obese women ${ }^{125}$ or showed that acute stress did not affect ghrelin levels in obese women. ${ }^{126}$ Whether confounding factors such as comorbidities contribute to these inconsistent results remains to be further investigated. However, since intravenous administration of ghrelin reduced blood pressure and sympathetic nerve activity in response to mental stress, ${ }^{127}$ ghrelin might still hold therapeutic potential under these conditions.

NUCB2/nesfatin-1 is involved in the stress response as initially described by Goebel and colleagues in 2009. ${ }^{128}$ Abdominal surgery as a model for physical stress ${ }^{129}$ and restraint stress as a psychological stressor ${ }^{128}$ activated NUCB2/nesfatin-1-containing neurons in the forebrain (including the hypothalamus) as well as the hindbrain (including the NTS) in rats which was confirmed in a subsequent study. ${ }^{130}$ Human studies showed increased circulating NUCB2/ nesfatin-1 levels in depressed patients compared to healthy individuals. ${ }^{131}$ Additionally, NUCB2/nesfatin-1 levels correlate posi- tively with anxiety, depression and perceived stress in female obese patients. ${ }^{132,133}$ Interestingly, in obese men an inverse correlation of NUCB2/nesfatin-1 and anxiety scores has been described ${ }^{133}$ giving rise to a sex-specific regulation of the peptide.

$\mathrm{CCK}$ seems to be involved in the mediation of anxiety-like behaviors. CCK-8S and CCK-8N increase anxiety-like behavior, an effect likely mediated by the $\mathrm{CCK}_{\mathrm{B}}$ as shown by decreased freezing behavior following injection of a $\mathrm{CCK}_{\mathrm{B}}$ receptor antagonist, LY225910, and increased freezing behavior by injection of the $\mathrm{CCK}_{\mathrm{B}}$ receptor agonist, CCK-4. ${ }^{134}$ Moreover, $\mathrm{CCK}_{\mathrm{B}}$ antagonism using LY288513 blunts conditioned fear stress induced by electric footshock in rats. ${ }^{135}$ In line with these findings, $\mathrm{CCK}_{\mathrm{B}} \mathrm{KO}$ mice showed an anxiolytic phenotype. ${ }^{136}$ Since mice lacking the $\mathrm{CCK}_{\mathrm{B}}$ display an increased body weight, ${ }^{137}$ brain CCK signaling seems to be involved in both, the modulation of anxiety as well as food intake. In humans, CCK has the most prominent role in panic disorder with exogenous CCK being able to provoke panic attacks and genetic variants of the $\mathrm{CCK}$ ligand and $\mathrm{CCK}_{\mathrm{B}}$ being potentially involved in the pathogenesis of panic disorder. ${ }^{138}$ Whether these alterations are also directly linked to alterations of food intake and body weight remains to be further addressed.

Similar to CCK, studies are lacking that investigate changes of peripheral GLP-1 expression due to stress, anxiety or depression. However, central GLP-1R stimulation acutely induces anxiety-like behavior in rats, while chronic administration of exendin-4 reduces depression-like behavior. ${ }^{139}$ These interesting differential effects of acute versus chronic GLP-1 signaling warrant further investigation.

Lastly, mice lacking the $\mathrm{Y}_{2}$ showed a suppression of anxiety and stress-related behavior ${ }^{140}$ suggesting that the PYY-mediated reduction in food intake might also be associated with or be secondary due to a modulation of anxiety and stress. These data show that food-intake regulatory peptides often exert multiple, if not pleiotropic, actions and especially effects related to anxiety and stress may be associated with an acute or chronic modulation of food intake.

\section{Modulation of Peptidergic Signaling in the Treatment of Obesity}

\section{Conservative Treatment: Physical Activity}

Since it is known that long-term physical activity is able to reduce body weight, ${ }^{141,142}$ an impact on gastrointestinal peptide hormones has been assumed as well. Exercise leads to a reduction of hunger, an effect observable shortly after performing sports. ${ }^{143}$ In line with this finding, the concentration of ghrelin is reduced 
following aerobic sports, ${ }^{144,145}$ as well as resistance exercise, ${ }^{145}$ likely contributing to the exercise-induced reduction of food intake. However, the exact role of ghrelin under these conditions needs to be further investigated as a correlation of hunger and circulating ghrelin was not detected, ${ }^{14,1145}$ likely suggesting an indirect effect of ghrelin and/or additional (peptidergic) mechanisms.

This hypothesis is underlined by the fact that the decrease of ghrelin levels during exercise is accompanied by reciprocal changes of anorexigenic hormones. Various studies reported that PYY concentrations rise during exercise in lean ${ }^{144,146,147}$ as well as obese ${ }^{148}$ individuals. Interestingly, one study showed that plasma concentrations of PYY increased at 5 hours after aerobic exercise, whereas anaerobic exercise did not affect PYY levels. ${ }^{144}$ Similar results were found for the impact of aerobic exercise on GLP-1 levels, which where elevated during and up to 1 hour after exercise. ${ }^{146-148} \mathrm{CCK}$ concentrations were elevated in men performing 30-minute cycling but did not change after chronic training over a period of 4 weeks. ${ }^{149}$ These results were confirmed by a 12 -week individually designed and supervised exercise program in overweight and obese individuals without changes in CCK concentrations at the end of the treatment period. ${ }^{150}$ Additionally, cumulative food intake was not altered after 12 weeks, ${ }^{150}$ which might point towards a rather acute effect of exercise on CCK. Taken together, these results show that acute exercise might affect food intake regulation by changes of the secretion of food intake-regulatory peptides from the gastrointestinal tract, whereas long-term exercise might lead to adaptive changes also blunting the effects on food intake.

Interestingly, different from other anorexigenic peptides, circulating NUCB2/nesfatin-1 decreased after acute exercise at the individual anaerobic threshold. ${ }^{151}$ In contrast to this acute regulation, aerobic exercise for a period of 8 weeks in overweight and obese females as well as a 6-week high-intensity interval training in overweight men increased circulating NUCB2/nesfatin-1 levels. ${ }^{152,153}$ These results were confirmed in women with type 2 diabetes mellitus who performed a 10-week resistance training. ${ }^{154}$ Since current data rather point to a central effect of nesfatin-1 on food intake, the observed peripheral changes of NUCB2/nesfatin-1 after acute and chronic exercise might impact on other regulatory processes such as glucose homeostasis.

\section{Conservative Treatment: Pharmacotherapy}

Despite the fact that our knowledge on the peptidergic regulation of food intake greatly increased during the past years, only few drugs targeting these hormones are on the market or are tested for the market. Nonetheless, several candidates are in the preclinical pipeline.

While several GHSR1a agonists such as ipamorelin ${ }^{155}$ or BIM-2831 $1^{156}$ are known and able to stimulate food intake, body weight gain, and gastrointestinal motility, ${ }^{155}$ there is a paucity on ghrelin antagonists. Intraperitoneal and intracerebroventricular administration of [D-Lys-3]-GHRP-6, a GHSR1a antagonist decreased food intake. ${ }^{157}$ However, GSK1614343, another GHSR1a antagonist, was not able to reduce ghrelin-stimulated food intake and unexpectedly itself stimulated food intake and body weight in rats and dogs ${ }^{158}$ likely due to GHSR1a-stimulating activity. It is also important to note that the ghrelin receptor GHSR1a displays considerable constitutive signaling activity, ${ }^{159}$ therefore blockade by classical agonists cannot fully abolish ghrelin signaling. In line with this assumption, central administration of a substance $\mathrm{P}$ derivate, an inverse agonist of the ghrelin receptor, was able to reduce food intake and body weight by decreasing the expression of NPY in the hypothalamus. ${ }^{160}$ Another possibility to reduce food intake is to inhibit the acylation of ghrelin. The most established GOAT inhibitor is GO-CoA-Tat, a peptide-based bisubstrate analogue that was shown to acutely reduce food intake in Siberian hamsters ${ }^{161}$ and rats $^{162}$ as well as body weight following repetitive intraperitoneal injections in mice. ${ }^{163}$ Whether these data can be translated to humans will have to be further investigated.

The food intake-reducing effect of nesfatin-1 is more readily observed after central injection ${ }^{164}$ hampering the potential therapeutic use as a target in the treatment of obesity. However, one study described the use of an intranasal application of nesfatin- 1 in rats inducing an acute reduction of food intake. ${ }^{165}$ Whether this holds true over a longer period of time and also in humans warrants further investigation.

As described above, a soybean trypsin inhibitor stimulates CCK release from duodenal I cells, an effect mimicked by the nonnutrient trypsin inhibitor, Camostat following oral administration in rats. ${ }^{166}$ It is known that CCK-8 reduces food intake in healthy volunteers. ${ }^{167}$ However, no data exist so far on the food intake-modulating effect of the endogenous form, CCK-58 in humans which has a longer half-life in the circulation and might be more effective in the reduction of food intake. ${ }^{53}$ While several CCK antagonists such as devazepide have been established to increase the amount of food intake or attenuate the anorexigenic effect of CCK in rats, ${ }^{168}$ there is a paucity on CCK analogs. The use of native CCK is difficult and hampered by the rapid endogenous degradation resulting in a short half-life. ${ }^{169}$ Amino terminal glycation of CCK-8 prolongs its half-life ${ }^{169}$ and might therefore be a potential target for short-time therapeutic reduction of food intake. However, longer application 
may be limited by the development of tolerance as observed after a 2-week intraperitoneal infusion of $\mathrm{CCK}$ in rats. ${ }^{170} \mathrm{~A}$ recently developed CCK-8 analogue showed more promising results: (pGluGln)-CCK-8 did not result in the development of an adaptation over a period of 28 days as reflected in a sustained decrease in food intake and body weight. ${ }^{171}$ Moreover, this compound is not subject to rapid degradation and was shown to be stable for 180 minutes post injection. ${ }^{171}$ Therefore, (pGlu-Gln)-CCK-8 as well as its polyethylene glycol-conjugated (PEGylated) form are promising targets in the treatment of obesity and deserve further testing.

Most of the studies investigating the effect of GLP-1 use the synthetic analogs exendin-4 and liraglutide, which are not degraded by dipeptidyl peptidase IV and able to cross the blood-brain barrier as active compounds to bind to the GLP-1R. ${ }^{70}$ Exendin- 4 injected intraperitoneally reduced cumulative food intake in mice by activating sensory afferent pathways due to binding to the GLP-1R, an effect attenuated by co-injection of capsaicin. ${ }^{172}$ These results were confirmed in rats, where intraperitoneal as well as subcutaneous injection of exendin-4 and liraglutide reduced cumulative food intake after acute injection. ${ }^{71}$ The same study investigated the effect of subacute intraperitoneal and subcutaneous administration of exendin-4 and liraglutide in diet-induced obese (DIO) rats over a period of 7 days. Both GLP-1 analogs reduced intake of a high fat/sucrose diet and led to a decrease of body weight. ${ }^{71}$ Taken together, these results show that exendin- 4 and liraglutide might be potential targets in the treatment of obesity. A recent meta-analysis comparing 21 studies investigating the effects of GLP-1 analogs on body weight changes in humans confirmed the results observed in rodents, and concluded that exenatide and liraglutide reduce body weight compared to controls. ${ }^{173}$ These compounds are therefore already used-liraglutide was recently approved for the drug treatment of obesity - in the clinic.

Although PYY levels are reduced in obese patients, its anorexic effect is still visible after exogenous administration. ${ }^{174}$ Therefore, PYY analogs and $\mathrm{Y}_{2}$ agonists were suggested as possible targets in the treatment of obesity. The injection of PYY reduces food intake, an effect absent in mice lacking the $\mathrm{Y}_{2}{ }^{100}$ Also, the use of a selective neuropeptide $\mathrm{Y}_{2}$ PEGylated peptide agonist consisting of a peptide core corresponding to residues 13 to 36 of human PYY and a non-peptidic moiety (2-mercaptonicotinic acid) at the peptide $\mathrm{N}$-terminus reduced food intake and body weight in lean rodents as well as in DIO rats. ${ }^{175}$ This anorexigenic effect was blocked by co-administration of the $Y_{2}$ agonist, BIIE0246, ${ }^{175}$ giving rise to direct competition at the $\mathrm{Y}_{2}$. Recently, a group developed a strategy to create dual target peptides intended to inhibit the GHSR1a while stimulating the $\mathrm{Y}_{2} \cdot{ }^{176}$ While the first results are promising in vitro, ${ }^{176}$ more research is needed in vivo under acute and chronic conditions in experimental animals and ultimately in humans.

\section{Surgical Treatment: Bariatric Surgery}

For patients suffering from severe obesity, bariatric surgery is the most effective treatment to reduce body weight. ${ }^{177}$ The most common procedures are Roux-en-Y gastric bypass (RYGB) and sleeve gastrectomy (SG), whereas gastric banding (GB) is not frequently performed anymore, and biliopancreatic diversion/duodenal switch (BPD/DS) often reserved as a second option. ${ }^{178}$ While our knowledge on the effectiveness of these techniques mentioned above (with the exception of gastric banding which does not result in a long-lasting reduction of body weight ${ }^{179}$ ) greatly increased over the past years, our knowledge on the underlying mechanisms is still incomplete. Besides the proposed restrictive and malabsorptive components of these techniques, ${ }^{180}$ an altered gastrointestinal peptide signaling very likely plays a role as well.

While GB had no effect on circulating ghrelin levels, ${ }^{181,182}$ $\mathrm{SG}^{183}$ and $\mathrm{BPD} / \mathrm{DS}^{184}$ led to a pronounced and long-lasting decrease of circulating ghrelin. This regulation seems different under conditions of RYGB with an early decrease of ghrelin ${ }^{184}$ followed by a later increase to reach preoperative levels, ${ }^{183,185}$ which may be associated with retained vagal signaling in these patients. ${ }^{185}$

In type 2 diabetic rats, NUCB2/nesfatin- 1 levels initially decreased after RYGB, but increased again at 2 months after the procedure, whereas SG did not affect nesfatin-1 levels. ${ }^{186}$ In patients with type 2 diabetes mellitus, both RYGB and SG reduced nesfatin-1 levels after surgery with a positive correlation with decreasing $\mathrm{BMI},{ }^{187}$ an adaptation possibly involved in the postoperative improvement of glucose control. A recent study showed that NUCB2/nesfatin-1 levels were decreased at 12 months following $\mathrm{BPD} / \mathrm{DS},{ }^{188}$ which positively correlated with weight loss. This might be an adaptation process as well, since it is known that peripheral nesfatin-1 is rather involved in hepatic lipolysis ${ }^{49}$ or glucose homeostasis ${ }^{51}$ than in body weight control.

The postprandial release of CCK, GLP-1, and PYY was increased following both $\mathrm{RYGB}^{189}$ and $\mathrm{SG},{ }^{183,190}$ a finding not observed after GB for GLP-1 and pancreatic polypeptide, ${ }^{181}$ while the regulation of CCK after GB is unknown so far. This increased postprandial release of CCK, GLP-1, and PYY might be due to faster delivery of nutrients to the distal intestinal tract following surgery and contribute to the improvement of glucose control as well as the reduction of food intake and subsequently body weight. Additionally, combined blockade of GLP-1 and PYY in type 2 dia- 

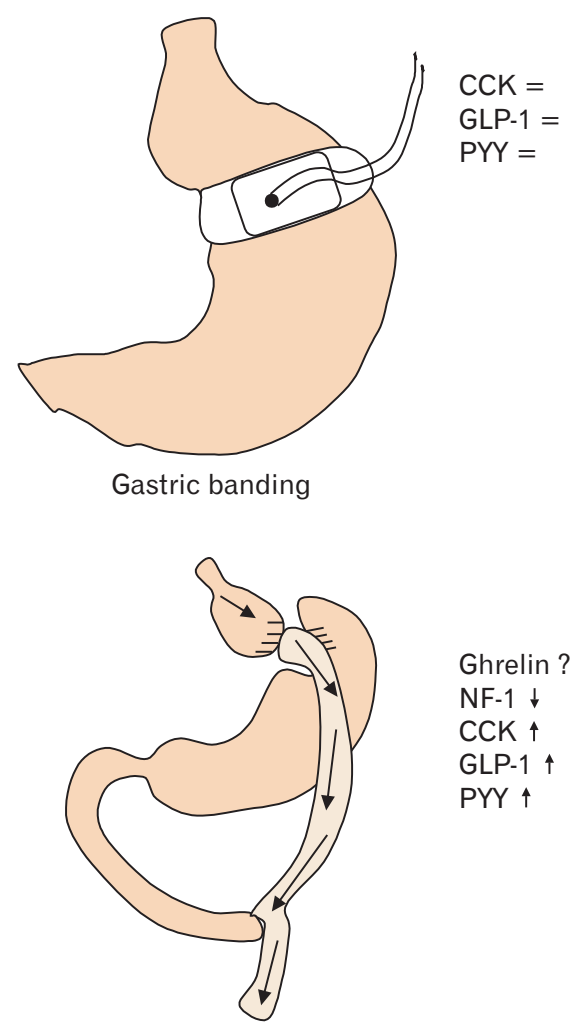

Roux-en-Y gastric bypass
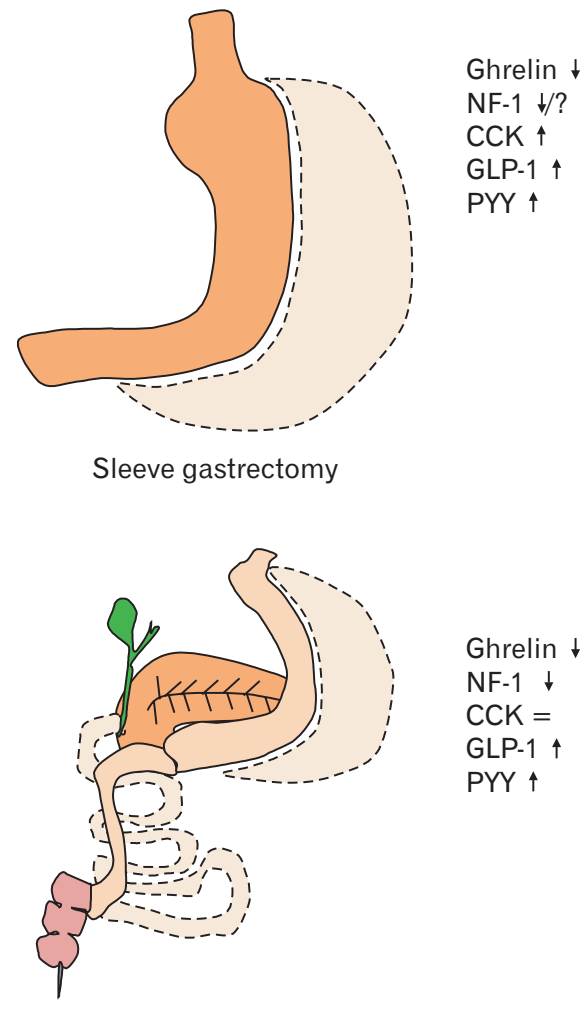

Biliopancreatic diversion
Figure 2. Effects of bariatric surgery on circulating levels of food intakeregulatory peptides. CCK, cholecystokinin; GLP-1, glucagon-like peptide 1; PYY, peptide tyrosine tyrosine; NF-1, nesfatin-1; $\downarrow$, decrease; $\uparrow$, increase; $=$, no change; ?, controversial data. betic patients following RYGB increased food intake, supporting the hypothesis that these 2 peptides play a role in the postoperative attenuation of food intake. ${ }^{191}$

Taken together, these results show that bariatric surgery greatly affects signaling of food intake-regulatory gastrointestinal peptides that likely contributes to the body weight-reducing effect of these procedures. The impact of bariatric surgery on gastrointestinal peptides is summarized in Figure 2.

\section{Surgical Treatment: Deep Brain Stimulation}

Since obesity still is an increasing threat to global health, new approaches have been tested to reduce body weight and food intake. One of the most promising and interesting approaches-besides the well-established use in Parkinson's disease ${ }^{192,193}$ and depres$\operatorname{sion}^{194}$ - is the application of deep brain stimulation (DBS), which is a minimally invasive and reversible method to modulate the central neuronal network. ${ }^{195}$ Interesting regional targets of the brain encompass the LHA, ventromedial hypothalamus (VMH) and the core and shell of the nucleus accumbens (NAc). ${ }^{196}$

Recently, a study investigated the effects of bilateral DBS in the LHA in 3 morbidly obese patients. The authors did neither report any serious side effects nor effects on body weight gain with the DBS settings used for movement disorders. ${ }^{197}$ However, when DBS stimulation was performed in the monopolar mode, the resting metabolic rate increased in 2 out of 3 patients and all 3 patients reported a decreased urge to eat. ${ }^{197}$ The follow-up investigations under monopolar settings showed a weight loss ranging from 12.3$16.4 \%$ in 2 of the 3 patients (and $0.9 \%$ in the third patient). ${ }^{197}$ Interestingly, food intake-regulatory peptides such as insulin, insulinlike growth factor, ghrelin, leptin, NPY, AgRP, and PYY were not altered under these conditions ${ }^{197}$ giving rise to local mechanisms. These results on food intake and body weight are extended by animal studies investigating the effects of bilateral DBS of the LHA in obese Zucker rats, which decreased food intake after 15 days of stimulation associated with a slight reduction of body weight that did not reach statistical significance. ${ }^{198}$ Taken together, monopolar stimulation seems to be necessary in order to induce weight loss. Although the LHA might be a promising target area, more research investigating larger patient populations over a longer follow-up period is needed to better characterize these effects.

Application of DBS to the VMH of a morbidly obese patient produced several unexpected side effects affecting memory or recol- 
lection. ${ }^{199}$ No weight changes were seen during the first 6 months using monopolar stimulation at $130 \mathrm{~Hz} .{ }^{199}$ However, after lowering the frequency to $50 \mathrm{~Hz}$ the patient lost $12 \mathrm{~kg}$ in 5 months and reported a reduced desire to eat. ${ }^{199}$ Subsequent studies were performed in female Göttingen minipigs, which were fed a restricted diet for one month after surgery without stimulation, followed by a 2-months period with twice the amount of food and half of the animals receiving DBS $50 \mathrm{~Hz}$ within the $\mathrm{VMH}$, while the other half was not stimulated. ${ }^{200}$ No motoric or behavioral side effects were monitored and all animals consumed the increased amount of food; however, the DBS-treated animals showed a reduced cumulative weight gain compared to non-stimulated pigs. ${ }^{200}$ This points towards a DBS-mediated increase in energy expenditure resulting in a reduction of body weight. In 2 vervet monkeys, bilateral DBS (monopolar, $185 \mathrm{~Hz}$ ) of the $\mathrm{VMH}$ increased food consumption without serious side effects, ${ }^{201}$ while a study in rats with unilateral, bipolar (150 and $500 \mathrm{~Hz}$ ) DBS stimulation of the VMH did not show changes in body weight after 32 days of stimulation. ${ }^{202}$ Whether these different results are due to species differences or differences in the strength and mode of stimulation remains to be further investigated. In order to possibly target the VMH to treat obesity further analyses are necessary, especially observations of psychological and behavioral side effects. Until then, other areas appear to be more promising targets.

Another interesting approach is to target the NAc as part of the reward circuitry. The NAc is divided into core and shell and was first targeted to treat neuropsychiatric disorders, like Tourette's syndrome ${ }^{203}$ or alcoholism. ${ }^{204}$ Based on these studies, it is known that electrical stimulation of the NAc is safe and feasible in humans. ${ }^{196}$
Direct stimulation of the NAc shell results in a modulation (either stimulation or inhibition) of food intake, ${ }^{205,206}$ an effect likely involving GLP-1 signaling. ${ }^{207,208}$ Treatment of the NAc shell and core with exendin-4 reduced food intake, especially of highly palatable food. ${ }^{207}$ However, only injection of exendin-4 into the NAc core reduced intake of $15 \%$ sucrose, whereas no effects on sucrose intake were observed after injection into the NAc shell. ${ }^{207}$ On the other hand, antagonism of GLP-1 signaling using exendin-9 injected into the NAc core and shell increased food intake. ${ }^{207}$ These data point towards a role of the endogenous GLP-1 signaling in the NAc to regulate food intake. Also, $\mathrm{CCK}$ is involved in the regulation of palatable food intake by affecting the NAc as shown in rats. ${ }^{209}$ Moreover, ghrelin injected into the NAc also stimulates food intake ${ }^{210}$ and increases extracellular dopamine levels following administration into the NAc shell. ${ }^{211}$ This indicates that the NAc shell might be an interesting target to increase food intake, as shown by a Dutch group that reported an increase of food intake in rats after DBS stimulation of the NAc medial shell, whereas DBS stimulation of the NAc core did not alter food intake. ${ }^{205}$ Interestingly, subsequent research in DIO rats showed that DBS stimulation of the NAc shell reduced food intake and body weight gain despite the fact that dopamine levels were increased in the NAc shell. ${ }^{206}$ Whether these discrepancies are due to different settings of stimulation, species or nutritional status needs to be further elucidated. The main effects of DBS on body weight and food intake are summarized in the table.

\section{Conclusion}

Although the basic mechanisms regulating hunger and satiety

Table. Overview of Current Studies on the Effects of Deep Brain Stimulation on Body Weight and Food Intake

\begin{tabular}{|c|c|c|c|c|}
\hline Target area & Mode & Species (n) & Results & References \\
\hline \multirow[t]{2}{*}{ Lateral hypothalamic area } & Bilateral, monopolar, $185 \mathrm{~Hz}$ & Humans (3) & 2 out of 3 : body weight $\downarrow$ & 197 \\
\hline & Bilateral, bipolar, $130 \mathrm{~Hz}$ & Obese Zucker rats (10) & Body weight $\downarrow$, food intake $\downarrow$ & 198 \\
\hline \multirow[t]{5}{*}{ Ventromedial hypothalamus } & Bilateral, monopolar, $50 \mathrm{~Hz}$ & Human (1) & Body weight $\downarrow$ & 199 \\
\hline & Bilateral, monopolar, $50 \mathrm{~Hz}$ & Göttingen minipigs (8) & Body weight gain $\downarrow$ & 200 \\
\hline & Bilateral, monopolar, $185 \mathrm{~Hz}$ & Vervet monkeys (2) & Food intake $\uparrow$ & 201 \\
\hline & Unilateral, bipolar, $150 \mathrm{~Hz}$ & Sprague Dawley rats (4) & No effect on body weight & 202 \\
\hline & Unilateral, bipolar, $500 \mathrm{~Hz}$ & Sprague Dawley rats (5) & No effect on body weight & 202 \\
\hline \multirow[t]{3}{*}{ Nucleus accumbens shell } & Bilateral, bipolar, $130 \mathrm{~Hz}$ & Wistar rats (8) & Food intake $\uparrow$ & 205 \\
\hline & $\begin{array}{l}\text { Unilateral, stimulation mode } \\
\text { not specified, } 130 \mathrm{~Hz}\end{array}$ & Diet-induced obese rats (8) & Body weight $\downarrow$, food intake $\downarrow$ & 206 \\
\hline & $\begin{array}{l}\text { Unilateral, stimulation mode } \\
\text { not specified, } 130 \mathrm{~Hz}\end{array}$ & Sprague Dawley rats (8) & No effects on body weight and food intake & 206 \\
\hline Nucleus accumbens core & Bilateral, bipolar, $130 \mathrm{~Hz}$ & Wistar rats (8) & No effect on food intake & 205 \\
\hline
\end{tabular}

$\downarrow$, decrease; $\uparrow$, increase. 
were extensively investigated, the complex and redundant system is still difficult to modulate. Besides (so far not very successful) conservative treatment options, surgical techniques can be applied. While bariatric surgery has become an effective treatment option for obesity associated with a long-term alteration of gastrointestinal peptidergic signaling, deep brain stimulation might be a promising and less invasive tool for the treatment of obesity.

\section{Financial support: None.}

\section{Conflicts of interest: None.}

Author contributions: Philip Prinz and Andreas Stengel wrote the review, Searched literature, and drew figures.

\section{References}

1. Mithieux G. Nutrient control of hunger by extrinsic gastrointestinal neurons. Trends Endocrinol Metab 2013;24:378-384.

2. Suzuki K, Jayasena CN, Bloom SR. Obesity and appetite control. Exp Diabetes Res 2012;2012:824305.

3. Stengel A, Mori M, Taché Y. The role of nesfatin-1 in the regulation of food intake and body weight: recent developments and future endeavors. Obes Rev2013;14:859-870.

4. Schwartz MW, Woods SC, Porte D Jr, Seeley RJ, Baskin DG. Central nervous system control of food intake. Nature 2000;404:661-671.

5. Camilleri M. Peripheral mechanisms in appetite regulation. Gastroenterology 2015;148:1219-1233.

6. Melvin A, le Roux CW, Docherty NG. The gut as an endocrine organ: role in the regulation of food intake and body weight. Curr Atheroscler Rep 2016;18:49.

7. Kairupan TS, Amitani H, Cheng KC, Runtuwene J, Asakawa A, Inui A. Role of gastrointestinal hormones in feeding behavior and obesity treatment. J Gastroenterol 2016;5 1:93-103.

8. Choudhury SM, Tan TM, Bloom SR. Gastrointestinal hormones and their role in obesity. Curr Opin Endocrinol Diabetes Obes 2016;23:1822.

9. Perry B, Wang Y. Appetite regulation and weight control: the role of gut hormones. Nutr Diabetes 2012;2:e26.

10. Mishra AK, Dubey V, Ghosh AR. Obesity: an overview of possible role(s) of gut hormones, lipid sensing and gut microbiota. Metabolism 2016;65:48-65.

11. Tschöp M, Smiley DL, Heiman ML. Ghrelin induces adiposity in rodents. Nature. 2000;407:908-913.

12. Date Y, Murakami N, Toshinai K, et al. The role of the gastric afferent vagal nerve in ghrelin-induced feeding and growth hormone secretion in rats. Gastroenterology 2002;123:1120-1128.

13. Banks WA, Tschöp M, Robinson SM, Heiman ML. Extent and direction of ghrelin transport across the blood-brain barrier is determined by its unique primary structure. J Pharmacol Exp Ther 2002;302:822-827.

14. Ariyasu H, Takaya K, Tagami T, et al. Stomach is a major source of circulating ghrelin, and feeding state determines plasma ghrelin-like immunoreactivity levels in humans. J Clin Endocrinol Metab 2001;86:47534758.

15. Date Y, Kojima M, Hosoda H, et al. Ghrelin, a novel growth hormonereleasing acylated peptide, is synthesized in a distinct endocrine cell type in the gastrointestinal tracts of rats and humans. Endocrinology 2000;141:4255-4261.

16. Kojima M, Hosoda H, Date Y, Nakazato M, Matsuo H, Kangawa K. Ghrelin is a growth-hormone-releasing acylated peptide from stomach. Nature 1999;402:656-660.

17. Yang J, Brown MS, Liang G, Grishin NV, Goldstein JL. Identification of the acyltransferase that octanoylates ghrelin, an appetite-stimulating peptide hormone. Cell 2008;132:387-396.

18. Gutierrez JA, Solenberg PJ, Perkins DR, et al. Ghrelin octanoylation mediated by an orphan lipid transferase. Proc Natl Acad Sci USA. 2008;105:6320-6325.

19. Stengel A, Goebel M, Wang L, Taché Y, Sachs G, Lambrecht NW. Differential distribution of ghrelin-O-acyltransferase (GOAT) immunoreactive cells in the mouse and rat gastric oxyntic mucosa. Biochem Biophys Res Commun 2010;392:67-71.

20. Stengel A, Hofmann T, Goebel-Stengel M, et al. Ghrelin and NUCB2/ nesfatin-1 are expressed in the same gastric cell and differentially correlated with body mass index in obese subjects. Histochem Cell Biol 2013;139:909-918.

21. Goebel-Stengel M, Hofmann T, Elbelt U, et al. The ghrelin activating enzyme ghrelin-O-acyltransferase (GOAT) is present in human plasma and expressed dependent on body mass index. Peptides 2013;43:13-19.

22. Wren AM, Small CJ, Ward HL, et al. The novel hypothalamic peptide ghrelin stimulates food intake and growth hormone secretion. Endocrinology 2000;141:4325-4328.

23. Wren AM, Seal LJ, Cohen MA, et al. Ghrelin enhances appetite and increases food intake in humans. J Clin Endocrinol Metab 2001;86:5992.

24. Gahete MD, Cordoba-Chacon J, Duran-Prado M, et al. Somatostatin and its receptors from fish to mammals. Ann N Y Acad Sci 2010;1200:43-52.

25. Guan XM, Yu H, Palyha OC, et al. Distribution of mRNA encoding the growth hormone secretagogue receptor in brain and peripheral tissues. Brain Res Mol Brain Res 1997;48:23-29.

26. Willesen MG, Kristensen P, Rømer J. Co-localization of growth hormone secretagogue receptor and NPY mRNA in the arcuate nucleus of the rat. Neuroendocrinology 1999;70:306-316.

27. Cowley MA, Smith RG, Diano S, et al. The distribution and mechanism of action of ghrelin in the CNS demonstrates a novel hypothalamic circuit regulating energy homeostasis. Neuron 2003;37:649-661.

28. Chen HY, Trumbauer ME, Chen AS, et al. Orexigenic action of peripheral ghrelin is mediated by neuropeptide $\mathrm{Y}$ and agouti-related protein. Endocrinology 2004;145:2607-2612.

29. Davies JS, Kotokorpi P, Eccles SR, et al. Ghrelin induces abdominal obesity via GHS-R-dependent lipid retention. Mol Endocrinol 2009;23:914-924. 
30. Lin L, Saha PK, Ma X, et al. Ablation of ghrelin receptor reduces adiposity and improves insulin sensitivity during aging by regulating fat metabolism in white and brown adipose tissues. Aging Cell 2011;10:9961010 .

31. Masuda Y, Tanaka T, Inomata N, et al. Ghrelin stimulates gastric acid secretion and motility in rats. Biochem Biophys Res Commun 2000;276:905-908

32. Murray CD, Martin NM, Patterson M, et al. Ghrelin enhances gastric emptying in diabetic gastroparesis: a double blind, placebo controlled, crossover study. Gut 2005;54:1693-1698.

33. Tong J, Prigeon RL, Davis HW, Bidlingmaier M, Tschöp MH, D'Alessio D. Physiologic concentrations of exogenously infused ghrelin reduces insulin secretion without affecting insulin sensitivity in healthy humans. J Clin Endocrinol Metab 2013;98:2536-2543.

34. Patterson M, Murphy KG, le Roux CW, Ghatei MA, Bloom SR. Characterization of ghrelin-like immunoreactivity in human plasma. J Clin Endocrinol Metab 2005;90:2205-2211.

35. Inhoff T, Mönnikes H, Noetzel S, et al. Desacyl ghrelin inhibits the orexigenic effect of peripherally injected ghrelin in rats. Peptides 2008;29:2159-2168.

36. Fernandez G, Cabral A, Cornejo MP, et al. Des-Acyl ghrelin directly targets the arcuate nucleus in a ghrelin-receptor independent manner and impairs the orexigenic effect of ghrelin. J Neuroendocrinol 2016;28:12349

37. Hirayama H, Shiina T, Shima T, et al. Contrasting effects of ghrelin and des-acyl ghrelin on the lumbo-sacral defecation center and regulation of colorectal motility in rats. Neurogastroenterol Motil 2011;22:11241131.

38. Oh-I S, Shimizu H, Satoh T, et al. Identification of nesfatin-1 as a satiety molecule in the hypothalamus. Nature 2006;443:709-712.

39. Stengel A, Goebel M, Wang L, et al. Central nesfatin-1 reduces darkphase food intake and gastric emptying in rats: differential role of corticotropin-releasing factor2 receptor. Endocrinology 2009; 150:49114919.

40. Goebel M, Stengel A, Wang L, Taché Y. Central nesfatin-1 reduces the nocturnal food intake in mice by reducing meal size and increasing intermeal intervals. Peptides 2011;32:36-43.

41. Kerbel B, Unniappan S. Nesfatin-1 suppresses energy intake, co-localises ghrelin in the brain and gut, and alters ghrelin, cholecystokinin and orexin mRNA expression in goldfish. J Neuroendocrinol 2012;24:366377.

42. Goebel M, Stengel A, Wang L, Lambrecht NW, Taché Y. Nesfatin-1 immunoreactivity in rat brain and spinal cord autonomic nuclei. Neurosci Lett 2009;452:241-246.

43. Stengel A, Goebel M, Yakubov I, et al. Identification and characterization of nesfatin-1 immunoreactivity in endocrine cell types of the rat gastric oxyntic mucosa. Endocrinology 2009;150:232-238.

44. Shimizu H, Oh-I S, Hashimoto K, et al. Peripheral administration of nesfatin-1 reduces food intake in mice: the leptin-independent mechanism. Endocrinology 2009;150:662-671.

45. Pan W, Hsuchou H, Kastin AJ. Nesfatin-1 crosses the blood-brain barrier without saturation. Peptides 2007;28:2223-2228.
46. Price TO, Samson WK, Niehoff ML, Banks WA. Permeability of the blood-brain barrier to a novel satiety molecule nesfatin-1. Peptides 2007;28:2372-2381.

47. Prinz P, Goebel-Stengel M, Teuffel P, Rose M, Klapp BF, Stengel A. Peripheral and central localization of the nesfatin-1 receptor using autoradiography in rats. Biochem Biophys Res Commun 2016;470:521527.

48. Mortazavi S, Gonzalez R, Ceddia R, Unniappan S. Long-term infusion of nesfatin-1 causes a sustained regulation of whole-body energy homeostasis of male Fischer 344 rats. Front Cell Dev Biol 2015;3:22.

49. Yin Y, Li Z, Gao L, Li Y, Zhao J, Zhang W. AMPK-dependent modulaion of hepatic lipid metabolism by nesfatin-1. Mol Cell Endocrinol 2015;417:20-26.

50. Watanabe A, Mochiki E, Kimura A, et al. Nesfatin-1 cuppresses gastric contractions and inhibits interdigestive migrating contractions in conscious dogs. Dig Dis Sci 2015;60:1595-1602.

51. Gonzalez R, Perry RL, Gao X, et al. Nutrient responsive nesfatin-1 regulates energy balance and induces glucose-stimulated insulin secretion in rats. Endocrinology 2011;152:3628-3637.

52. Riva M, Nitert MD, Voss U, et al. Nesfatin-1 stimulates glucagon and insulin secretion and beta cell NUCB2 is reduced in human type 2 diabetic subjects. Cell Tissue Res 2011;346:393-405.

53. Sayegh AI. The role of cholecystokinin receptors in the short-term control of food intake. Prog Mol Biol Transl Sci 2013;114:277-316.

54. Larsson LI, Rehfeld JF. Localization and molecular heterogeneity of cholecystokinin in the central and peripheral nervous system. Brain Res 1979;165:201-218.

55. Gibbs J, Young RC, Smith GP. Cholecystokinin decreases food intake in rats. J Comp Physiol Psychol 1973;84:488-495.

56. Stengel A, Keire D, Goebel M, et al. The RAPID method for blood processing yields new insight in plasma concentrations and molecular forms of circulating gut peptides. Endocrinology 2009;150:5113-5118.

57. Goebel-Stengel M, Stengel A, Wang L, Ohning G, Taché Y, Reeve JR, Jr. CCK-8 and CCK-58 differ in their effects on nocturnal solid meal pattern in undisturbed rats. Am J Physiol Regul Integr Comp Physiol 2012;303:R850-R860.

58. Chey WY, Hitanant S, Hendricks J, Lorber SH. Effect of secretin and cholecystokinin on gastric emptying and gastric secretion in man. Gastroenterology 1970;58:820-827.

59. Raybould HE, Taché Y. Cholecystokinin inhibits gastric motility and emptying via a capsaicin-sensitive vagal pathway in rats. Am J Physiol 1988;255(2 Pt 1):G242-G246.

60. Gerner T. Pressure responses to OP-CCK compared to CCK-PZ in the antrum and fundus of isolated guinea-pig stomachs. Scand J Gastroenterol 1979;14:73-77.

61. Hill DR, Campbell NJ, Shaw TM, Woodruff GN. Autoradiographic localization and biochemical characterization of peripheral type CCK receptors in rat CNS using highly selective nonpeptide CCK antagonists. J Neurosci 1987;7:2967-2976.

62. Kissileff HR, Pi-Sunyer FX, Thornton J, Smith GP. C-terminal octapeptide of cholecystokinin decreases food intake in man. Am J Clin Nutr 1981;34:154-160. 
63. Greenberg D, Smith GP, Gibbs J. Intraduodenal infusions of fats elicit satiety in sham-feeding rats. Am J Physiol 1990;259(1 Pt 2):R110-R118.

64. Liddle RA, Green GM, Conrad CK, Williams JA. Proteins but not amino acids, carbohydrates, or fats stimulate cholecystokinin secretion in the rat. Am J Physiol 1986;251:G243-G248.

65. Corp ES, McQuade J, Moran TH, Smith GP. Characterization of type A and type B CCK receptor binding sites in rat vagus nerve. Brain Res 1993;623:161-166.

66. Smith GP, Jerome C, Cushin BJ, Eterno R, Simansky KJ. Abdominal vagotomy blocks the satiety effect of cholecystokinin in the rat. Science 1981;213:1036-1037.

67. Jordan J, Greenway FL, Leiter LA, et al. Stimulation of cholecystokinin-A receptors with GI181771X does not cause weight loss in overweight or obese patients. Clin Pharmacol Ther 2008;83:281-287.

68. South EH, Ritter RC. Capsaicin application to central or peripheral vagal fibers attenuates CCK satiety. Peptides 1988;9:601-612.

69. MacLean DB. Abrogation of peripheral cholecystokinin-satiety in the capsaicin treated rat. Regul Pept 1985;11:321-333.

70. Dailey MJ, Moran TH. Glucagon-like peptide 1 and appetite. Trends Endocrinol Metab 2013;24:85-91.

71. Hayes MR, Kanoski SE, Alhadeff AL, Grill HJ. Comparative effects of the long-acting GLP-1 receptor ligands, liraglutide and exendin-4, on food intake and body weight suppression in rats. Obesity (Silver Spring) 2011;19:1342-1349.

72. Edwards CM, Stanley SA, Davis R, et al. Exendin-4 reduces fasting and postprandial glucose and decreases energy intake in healthy volunteers. Am J Physiol Endocrinol Metab 2001;281:E155-E161.

73. Horowitz M, Flint A, Jones KL, et al. Effect of the once-daily human GLP-1 analogue liraglutide on appetite, energy intake, energy expenditure and gastric emptying in type 2 diabetes. Diabetes Res Clin Pract 2012;97:258-266.

74. Mojsov S, Heinrich G, Wilson IB, Ravazzola M, Orci L, Habener JF. Preproglucagon gene expression in pancreas and intestine diversifies at the level of post-translational processing. J Biol Chem 1986;261:1188011889.

75. Orskov C, Rabenhoj L, Wettergren A, Kofod H, Holst JJ. Tissue and plasma concentrations of amidated and glycine-extended glucagon-like peptide I in humans. Diabetes 1994;43:535-539.

76. Roberge JN, Brubaker PL. Regulation of intestinal proglucagonderived peptide secretion by glucose-dependent insulinotropic peptide in a novel enteroendocrine loop. Endocrinology 1993;133:233-240.

77. Reimer RA, Darimont C, Gremlich S, Nicolas-Métral V, Rüegg UT, Macé K. A human cellular model for studying the regulation of glucagon-like peptide-1 secretion. Endocrinology 2001;142:4522-4528.

78. Rocca AS, Brubaker PL. Role of the vagus nerve in mediating proximal nutrient-induced glucagon-like peptide-1 secretion. Endocrinology 1999;140:1687-1694.

79. Tang-Christensen M, Larsen PJ, Göke R, et al. Central administration of GLP-1-(7-36) amide inhibits food and water intake in rats. Am J Physiol 1996;271(4 Pt 2):R848-R856.

80. Chelikani PK, Haver AC, Reidelberger RD. Intravenous infusion of glucagon-like peptide-1 potently inhibits food intake, sham feeding, and gastric emptying in rats. Am J Physiol Regul Integr Comp Physiol 2005;288:R1695-R1706.

81. Gutzwiller JP, Göke B, Drewe J, et al. Glucagon-like peptide-1: a potent regulator of food intake in humans. Gut 1999;44:81-86.

82. Hellström PM, Näslund E, Edholm T, et al. GLP-1 suppresses gastrointestinal motility and inhibits the migrating motor complex in healthy subjects and patients with irritable bowel syndrome. Neurogastroenterol Motil 2008;20:649-659.

83. Schirra J, Nicolaus M, Roggel R, et al. Endogenous glucagon-like peptide 1 controls endocrine pancreatic secretion and antro-pyloro-duodenal motility in humans. Gut 2006;55:243-251.

84. Imeryüz N, Yeğen BC, Bozkurt A, Coşkun T, Villanueva-Peñacarrillo ML, Ulusoy NB. Glucagon-like peptide-1 inhibits gastric emptying via vagal afferent-mediated central mechanisms. Am J Physiol 1997;273(4 Pt 1):G920-G927.

85. Tolessa T, Gutniak M, Holst JJ, Efendic S, Hellstrom PM. Glucagonlike peptide-1 retards gastric emptying and small bowel transit in the rat: effect mediated through central or enteric nervous mechanisms. Dig Dis Sci 1998;43:2284-2290.

86. Larsen PJ, Tang-Christensen M, Holst JJ, Orskov C. Distribution of glucagon-like peptide-1 and other preproglucagon-derived peptides in the rat hypothalamus and brainstem. Neuroscience 1997;77:257-270.

87. Nakagawa A, Satake H, Nakabayashi H, et al. Receptor gene expression of glucagon-like peptide-1, but not glucose-dependent insulinotropic polypeptide, in rat nodose ganglion cells. Auton Neurosci 2004;110:3643.

88. Abbott CR, Monteiro M, Small CJ, et al. The inhibitory effects of peripheral administration of peptide $\mathrm{YY}(3-36)$ and glucagon-like peptide- 1 on food intake are attenuated by ablation of the vagal-brainstemhypothalamic pathway. Brain Res 2005;1044:127-131.

89. Baggio LL, Huang Q, Brown TJ, Drucker DJ. Oxyntomodulin and glucagon-like peptide-1 differentially regulate murine food intake and energy expenditure. Gastroenterology 2004;127:546-558.

90. Barrera JG, Jones KR, Herman JP, D’Alessio DA, Woods SC, Seeley RJ. Hyperphagia and increased fat accumulation in two models of chronic CNS glucagon-like peptide-1 loss of function. J Neurosci 2011;31:3904-3913.

91. Sandoval DA, Bagnol D, Woods SC, D’Alessio DA, Seeley RJ. Arcuate glucagon-like peptide 1 receptors regulate glucose homeostasis but not food intake. Diabetes 2008;57:2046-2054.

92. Orskov C, Poulsen SS, Møller M, Holst JJ. Glucagon-like peptide I receptors in the subfornical organ and the area postrema are accessible to circulating glucagon-like peptide I. Diabetes 1996;45:832-835.

93. Merchenthaler I, Lane M, Shughrue P. Distribution of pre-proglucagon and glucagon-like peptide-1 receptor messenger RNAs in the rat central nervous system. J Comp Neurol 1999;403:261-280.

94. Secher A, Jelsing J, Baquero AF, et al. The arcuate nucleus mediates GLP-1 receptor agonist liraglutide-dependent weight loss. J Clin Invest 2014;124:4473-4488

95. Hansen L, Deacon CF, Orskov C, Holst JJ. Glucagon-like peptide-1-(7-36)amide is transformed to glucagon-like peptide-1-(9-36) amide by dipeptidyl peptidase IV in the capillaries supplying the $\mathrm{L}$ cells 
of the porcine intestine. Endocrinology 1999;140:5356-5363.

96. Krieger JP, Arnold M, Pettersen KG, Lossel P, Langhans W, Lee SJ. Knockdown of GLP-1 receptors in vagal afferents affects normal food intake and glycemia. Diabetes 2016;65:34-43.

97. Manning S, Batterham RL. The role of gut hormone peptide YY in energy and glucose homeostasis: twelve years on. Annu Rev Physiol 2014;76:585-608.

98. Mentlein R, Dahms P, Grandt D, Krüger R. Proteolytic processing of neuropeptide $\mathrm{Y}$ and peptide YY by dipeptidyl peptidase IV. Regul Pept 1993;49:133-144.

99. Tatemoto K. Isolation and characterization of peptide YY (PYY), a candidate gut hormone that inhibits pancreatic exocrine secretion. Proc Natl Acad Sci USA 1982;79:2514-2518.

100. Batterham RL, Cowley MA, Small CJ, et al. Gut hormone PYY(3-36) physiologically inhibits food intake. Nature 2002;418:650-654.

101. Abbott CR, Small CJ, Kennedy AR, et al. Blockade of the neuropeptide Y Y2 receptor with the specific antagonist BIIE0246 attenuates the effect of endogenous and exogenous peptide $\mathrm{YY}(3-36)$ on food intake. Brain Res 2005;1043:139-144.

102. Batterham RL, Bloom SR. The gut hormone peptide YY regulates appetite. Ann. N Y Acad Sci 2003;994:162-168.

103. Broberger C, Landry M, Wong H, Walsh JN, Höokfelt T. Subtypes $\mathrm{Y} 1$ and $\mathrm{Y} 2$ of the neuropeptide $\mathrm{Y}$ receptor are respectively expressed in pro-opiomelanocortin- and neuropeptide-Y-containing neurons of the rat hypothalamic arcuate nucleus. Neuroendocrinology 1997;66:393-408.

104. Nonaka N, Shioda S, Niehoff ML, Banks WA. Characterization of blood-brainbarrier permeability to PYY3-36 in the mouse. J Pharmacol Exp Ther 2003;306:948-953.

105. Koda S, Date Y, Murakami N, et al. The role of the vagal nerve in peripheral PYY3-36-induced feeding reduction in rats. Endocrinology 2005;146:2369-2375.

106. Gribble FM. The gut endocrine system as a coordinator of postprandial nutrient homoeostasis. Proc Nutr Soc 2012;71:456-462.

107. Liddle RA, Goldfine ID, Rosen MS, Taplitz RA, Williams JA. Cholecystokinin bioactivity in human plasma. Molecular forms, responses to feeding, and relationship to gallbladder contraction. J Clin Invest 1985; 75:1144-1152.

108. Olsen O, Schaffalitzky de Muckadell OB, Cantor P. The significance of plasma CCK and secretin in the oleate-stimulated pancreatico-biliary secretion in man. Int J Pancreatol 1986;1:363-372.

109. Pilichiewicz AN, Chaikomin R, Brennan IM, et al. Load-dependent effects of duodenal glucose on glycemia, gastrointestinal hormones, antropyloroduodenal motility, and energy intake in healthy men. Am J Physiol Endocrinol Metab 2007;293:E743-E753.

110. Yonezawa H. Discrepancy between the potency of various trypsin inhibitors to inhibit trypsin activity and the potency to release biologically active cholecystokinin-pancreozymin. Jpn J Physiol 1984;34:849-856.

111. Crijanovic N, Isaacs NJ, Rayner CK, Feinle-Bisset C, Young RL, Little TJ. Duodenal fatty acid sensor and transporter expression following acute fat exposure in healthy lean humans. Clin Nutr 2017;36:564-569.

112. Elliott RM, Morgan LM, Tredger JA, Deacon S, Wright J, Marks V. Glucagon-like peptide-1 (7-36)amide and glucose-dependent in- sulinotropic polypeptide secretion in response to nutrient ingestion in man: acute post-prandial and 24-h secretion patterns. J Endocrinol 1993;138:159-166.

113. Jang HJ, Kokrashvili Z, Theodorakis MJ, et al. Gut-expressed gustducin and taste receptors regulate secretion of glucagon-like peptide-1. Proc Natl Acad Sci USA 2007;104:15069-15074.

114. le Roux CW, Batterham RL, Aylwin SJ, et al. Attenuated peptide YY release in obese subjects is associated with reduced satiety. Endocrinology 2006;147:3-8.

115. Chan JL, Stoyneva V, Kelesidis T, Raciti P, Mantzoros CS. Peptide YY levels are decreased by fasting and elevated following caloric intake but are not regulated by leptin. Diabetologia 2006;49:169-173.

116. Greenman Y, Golani N, Gilad S, Yaron M, Limor R, Stern N. Ghrelin secretion is modulated in a nutrient- and gender-specific manner. Clin Endocrinol (Oxf) 2004;60:382-388.

117. Nishi $Y$, Hiejima H, Hosoda H, et al. Ingested medium-chain fatty acids are directly utilized for the acyl modification of ghrelin. Endocrinology 2005;146:2255-2264.

118. Mohan H, Ramesh N, Mortazavi S, Le A, Iwakura H, Unniappan S. Nutrients differentially regulate nucleobindin-2/nesfatin-1 in vitro in cultured stomach ghrelinoma (MGN3-1) cells and in vivo in male mice. PLoS One 2014;9:e115102.

119. Lutter M, Sakata I, Osborne-Lawrence S, et al. The orexigenic hormone ghrelin defends against depressive symptoms of chronic stress. Nat Neurosci 2008;11:752-753.

120. Florentzson M, Svensson K, Astin-Nielsen M, Andersson K, Håkanson R, Lindstrom E. Low gastric acid and high plasma gastrin in highanxiety Wistar Kyoto rats. Scand J Gastroenterol 2009;44:401-407.

121. Asakawa A, Inui A, Kaga T, et al. A role of ghrelin in neuroendocrine and behavioral responses to stress in mice. Neuroendocrinology 2001;74:143-147.

122. Kristenssson E, Sundqvist M, Astin M, et al. Acute psychological stress raises plasma ghrelin in the rat. Regul Pept 2006;134:114-117.

123. Geliebter A, Carnell S, Gluck ME. Cortisol and ghrelin concentrations following a cold pressor stress test in overweight individuals with and without night eating. Int J Obes (Lond) 2013;37:1104-1108.

124. Gluck ME, Yahav E, Hashim SA, Geliebter A. Ghrelin levels after a cold pressor stress test in obese women with binge eating disorder. Psychosom Med 2014;76:74-79.

125. Buss J, Havel PJ, Epel E, Lin J, Blackburn E, Daubenmier J. Associations of ghrelin with eating behaviors, stress, metabolic factors, and telomere length among overweight and obese women: preliminary evidence of attenuated ghrelin effects in obesity? Appetite 2014;76:84-94.

126. Kiessl GR, Laessle RG. Stress does not affect ghrelin secretion in obese and normal weight women. Eat Weight Disord 2017;22:79-84.

127. Lambert E, Lambert G, Ika-Sari C, et al. Ghrelin modulates sympathetic nervous system activity and stress response in lean and overweight men. Hypertension 2011;58:43-50.

128. Goebel M, Stengel A, Wang L, Taché Y. Restraint stress activates nesfatin-1-immunoreactive brain nuclei in rats. Brain Res 2009;1300:114124.

129. Stengel A, Goebel M, Wang L, Taché Y. Abdominal surgery activates 
nesfatin-1 immunoreactive brain nuclei in rats. Peptides. 2010;31:263270.

130. Yoshida N, Maejima Y, Sedbazar U, et al. Stressor-responsive central nesfatin-1 activates corticotropin-releasing hormone, noradrenaline and serotonin neurons and evokes hypothalamic-pituitary-adrenal axis. Aging (Albany NY) 2010;2:775-784.

131. Ari M, Ozturk OH, Bez Y, Oktar S, Erduran D. High plasma nesfatin-1 level in patients with major depressive disorder. Prog Neuropsychopharmacol Biol Psychiatry 2011;35:497-500.

132. Hofmann T, Stengel A, Ahnis A, Buße P, Elbelt U, Klapp BF. NUCB2/nesfatin-1 is associated with elevated scores of anxiety in female obese patients. Psychoneuroendocrinology 2013;38:2502-2510.

133. Hofmann T, Elbelt U, Ahnis A, Rose M, Klapp BF, Stengel A. Sexspecific regulation of NUCB2/nesfatin-1: differential implication in anxiety in obese men and women. Psychoneuroendocrinology 2015;60:130137.

134. Wang H, Wong PT, Spiess J, Zhu YZ. Cholecystokinin-2 (CCK2) receptor-mediated anxiety-like behaviors in rats. Neurosci Biobehav Rev 2005;29:1361-1373.

135. Izumi T, Inoue T, Tsuchiya K, Hashimoto S, Ohmori T, Koyama T. Effect of the selective CCKB receptor antagonist LY288513 on conditioned fear stress in rats. Eur J Pharmacol 1996;300:25-31.

136. Raud S, Runkorg K, Veraksits A, et al. Targeted mutation of CCK2 receptor gene modifies the behavioural effects of diazepam in female mice. Psychopharmacology (Berl). 2003;168:417-25.

137. Chen $\mathrm{H}$, Kent $\mathrm{S}$, Morris MJ. Is the CCK2 receptor essential for normal regulation of body weight and adiposity? Eur J Neurosci 2006;24:14271433.

138. Zwanzger P, Domschke K, Bradwejn J. Neuronal network of panic disorder: the role of the neuropeptide cholecystokinin. Depress Anxiety 2012;29:762-774.

139. Anderberg RH, Richard JE, Hansson C, Nissbrandt H, Bergquist F, Skibicka KP. GLP-1 is both anxiogenic and antidepressant; divergent effects of acute and chronic GLP-1 on emotionality. Psychoneuroendocrinology 2016;65:54-66.

140. Tschenett A, Singewald N, Carli M, et al. Reduced anxiety and improved stress coping ability in mice lacking NPY-Y2 receptors. Eur J Neurosci 2003;18:143-148.

141. Donnelly JE, Hill JO, Jacobsen DJ, et al. Effects of a 16-month randomized controlled exercise trial on body weight and composition in young, overweight men and women: the Midwest Exercise Trial. Arch Intern Med 2003;163:1343-1350.

142. Jakicic JM, Marcus BH, Lang W, Janney C. Effect of exercise on 24-month weight loss maintenance in overweight women. Arch Intern Med 2008;168:1550-1559; discussion 1550-1560.

143. King NA, Burley VJ, Blundell JE. Exercise-induced suppression of appetite: effects on food intake and implications for energy balance. Eur J Clin Nutr 1994;48:715-724.

144. Broom DR, Batterham RL, King JA, Stensel DJ. Influence of resistance and aerobic exercise on hunger, circulating levels of acylated ghrelin, and peptide YY in healthy males. Am J Physiol Regul Integr Comp Physiol 2009;296:R29-R35.
145. Broom DR, Stensel DJ, Bishop NC, Burns SF, Miyashita M. Exerciseinduced suppression of acylated ghrelin in humans. J Appl Physiol 2007;102:2165-2171.

146. Martins C, Morgan LM, Bloom SR, Robertson MD. Effects of exercise on gut peptides, energy intake and appetite. J Endocrinol 2007;193:251-258.

147. Ueda SY, Yoshikawa T, Katsura Y, Usui T, Fujimoto S. Comparable effects of moderate intensity exercise on changes in anorectic gut hormone levels and energy intake to high intensity exercise. J Endocrinol 2009;203:357-364.

148. Ueda SY, Yoshikawa T, Katsura Y, Usui T, Nakao H, Fujimoto S. Changes in gut hormone levels and negative energy balance during aerobic exercise in obese young males. J Endocrinol 2009;201:151-159.

149. Bailey DM, Davies B, Castell LM, Newsholme EA, Calam J. Physical exercise and normobaric hypoxia: independent modulators of peripheral cholecystokinin metabolism in man. J Appl Physiol 2001;90:105-113.

150. Martins C, Kulseng B, Rehfeld JF, King NA, Blundell JE. Effect of chronic exercise on appetite control in overweight and obese individuals. Med Sci Sports Exerc 2013;45:805-812.

151. Mohebbi H, Nourshahi M, Ghasemikaram M, Safarimosavi S. Effects of exercise at individual anaerobic threshold and maximal fat oxidation intensities on plasma levels of nesfatin-1 and metabolic health biomarkers. J Physiol Biochem 2015;71:79-88.

152. Jafari M, Mogharnasi M. The protective effect of different methods of exercise training on plasma levels of nesfatin-1, cardiorespiratory endurance and body composition in overweight and obese females. Mod Care J 2015; 12:61-67.

153. Ahmadizad S, Avansar AS, Ebrahim K, Avandi M, Ghasemikaram M. The effects of short-term high-intensity interval training vs. moderateintensity continuous training on plasma levels of nesfatin-1 and inflammatory markers. Horm Mol Biol Clin Investig 2015;21:165-173.

154. Tabas AT, Mogharnasi M. The effect of 10 weeks resistance training on serum levels of nesfatin-1 and insulin resistance in women with type 2 diabetes. Iran J Diabetes Metab 2016;14:179-188.

155. Venkova K, Mann W, Nelson R, Greenwood-Van Meerveld B. Efficacy of ipamorelin, a novel ghrelin mimetic, in a rodent model of postoperative ileus. J Pharmacol Exp Ther 2009;329:1110-1116.

156. Strassburg S, Anker SD, Castaneda TR, Burget L, Perez-Tilve D, Pfluger PT, et al. Long-term effects of ghrelin and ghrelin receptor agonists on energy balance in rats. Am J Physiol Endocrinol Metab 2008;295:E78-E84.

157. Asakawa A, Inui A, Kaga T, et al. Antagonism of ghrelin receptor reduces food intake and body weight gain in mice. Gut 2003;52:947-952.

158. Costantini VJ, Vicentini E, Sabbatini FM, et al. GSK1614343, a novel ghrelin receptor antagonist, produces an unexpected increase of food intake and body weight in rodents and dogs. Neuroendocrinology 2011;94:158-168.

159. Mear Y, Enjalbert A, Thirion S. GHS-R1a constitutive activity and its physiological relevance. Front Neurosci 2013;7:87.

160. Petersen PS, Woldbye DP, Madsen AN, et al. In vivo characterization of high basal signaling from the ghrelin receptor. Endocrinology 2009;150:4920-4930. 
161. Teubner BJ, Garretson JT, Hwang Y, Cole PA, Bartness TJ. Inhibition of ghrelin $O$-acyltransferase attenuates food deprivation-induced increases in ingestive behavior. Horm. Behav. 2013;63:667-673.

162. Teuffel P, Wang L, Prinz P, et al. Treatment with the ghrelin-Oacyltransferase (GOAT) inhibitor GO-CoA-Tat reduces food intake by reducing meal frequency in rats. J Physiol Pharmacol 2015;66:493-503.

163. Barnett BP, Hwang Y, Taylor MS, et al. Glucose and weight control in mice with a designed ghrelin $O$-acyltransferase inhibitor. Science 2010;330:1689-1692.

164. Prinz P, Stengel A. Nesfatin-1: current status as a peripheral hormone and future prospects. Curr Opin Pharmacol 2016;31:19-24.

165. Shimizu H, Oh IS, Okada S, Mori M. Nesfatin-1: an overview and future clinical application. Endocr J 2009;56:537-543.

166. Göke B, Printz H, Koop I, et al. Endogenous CCK release and pancreatic growth in rats after feeding a proteinase inhibitor (camostate). Pancreas 1986;1:509-515.

167. Stacher G, Steinringer H, Schmierer G, Schneider C, Winklehner S. Cholecystokinin octapeptide decreases intake of solid food in man. Peptides 1982;3:133-136.

168. Corwin RL, Gibbs J, Smith GP. Increased food intake after type A but not type B cholecystokinin receptor blockade. Physiol Behav 1991;50:255-258.

169. O'Harte FP, Mooney MH, Kelly CM, Flatt PR. Glycated cholecystokinin- 8 has an enhanced satiating activity and is protected against enzymatic degradation. Diabetes 1998;47:1619-1624.

170. Crawley JN, Beinfeld MC. Rapid development of tolerance to the behavioural actions of cholecystokinin. Nature 1983;302:703-706.

171. Irwin N, Frizelle P, Montgomery IA, Moffett RC, O'Harte FP, Flatt PR. Beneficial effects of the novel cholecystokinin agonist (pGluGln)-CCK-8 in mouse models of obesity/diabetes. Diabetologia 2012;55:2747-2758.

172. Talsania T, Anini Y, Siu S, Drucker DJ, Brubaker PL. Peripheral exendin-4 and peptide $\mathrm{YY}^{3-36}$ synergistically reduce food intake through different mechanisms in mice. Endocrinology 2005;146:3748-3756.

173. Robinson LE, Holt TA, Rees K, Randeva HS, O'Hare JP. Effects of exenatide and liraglutide on heart rate, blood pressure and body weight: systematic review and meta-analysis. BMJ Open 2013;3.

174. Batterham RL, Cohen MA, Ellis SM, et al. Inhibition of food intake in obese subjects by peptide $\mathrm{YY}_{3-36}$. N Engl J Med 2003;349:941-948.

175. Ortiz AA, Milardo LF, DeCarr LB, et al. A novel long-acting selective neuropeptide $\mathrm{Y} 2$ receptor polyethylene glycol-conjugated peptide agonist reduces food intake and body weight and improves glucose metabolism in rodents. J Pharmacol Exp Ther 2007;323:692-700.

176. Kilian TM, Kloting N, Bergmann R, et al. Rational design of dual peptides targeting ghrelin and $\mathrm{Y} 2$ receptors to regulate food intake and body weight. J Med Chem 2015;58:4180-4193.

177. Maggard MA, Shugarman LR, Suttorp M, et al. Meta-analysis: surgical treatment of obesity. Ann Intern Med 2005;142:547-559.

178. Buchwald H, Oien DM. Metabolic/bariatric surgery worldwide 2011. Obes Surg2013;23:427-436.

179. Sjostrom L, Lindroos AK, Peltonen M, et al. Lifestyle, diabetes, and cardiovascular risk factors 10 years after bariatric surgery. $\mathrm{N}$ Engl $\mathrm{J}$
Med 2004;351:2683-2693.

180. Concors SJ, Ecker BL, Maduka R, et al. Complications and surveillance after bariatric surgery. Curr Treat Options Neurol 2016;18:5.

181. Bose M, Machineni S, Oliván B, et al. Superior appetite hormone profile after equivalent weight loss by gastric bypass compared to gastric banding. Obesity (Silver Spring) 2010;18:1085-1091.

182. Langer FB, Reza Hoda MA, Bohdjalian A, et al. Sleeve gastrectomy and gastric banding: effects on plasma ghrelin levels. Obes Surg 2005;15:1024-1029.

183. Peterli R, Steinert RE, Woelnerhanssen B, et al. Metabolic and hormonal changes after laparoscopic Roux-en-Y gastric bypass and sleeve gastrectomy: a randomized, prospective trial. Obes Surg 2012;22:740748.

184. Cummings DE, Weigle DS, Frayo RS, et al. Plasma ghrelin levels after diet-induced weight loss or gastric bypass surgery. N Engl J Med 2002;346:1623-1630.

185. Sundbom M, Holdstock C, Engstrom BE, Karlsson FA. Early changes in ghrelin following Roux-en-Y gastric bypass: influence of vagal nerve functionality? ObesSurg 2007;17:304-310.

186. Xia Z, Wang G, Li H, et al. Influence of bariatric surgery on the expression of nesfatin- 1 in rats with type 2 diabetes mellitus. Curr Pharm Des 2015;21:1464-1471.

187. Lee WJ, Chen CY, Ser KH, et al. Differential influences of gastric bypass and sleeve gastrectomy on plasma nesfatin- 1 and obestatin levels in patients with type 2 diabetes mellitus. Curr Pharm Des 2013;19:58305835.

188. St-Pierre DH, Martin J, Shimizu H, et al. Association between nesfatin-1 levels and metabolic improvements in severely obese patients who underwent biliopancreatic derivation with duodenal switch. Peptides 2016;86:6-12.

189. Korner J, Inabnet W, Conwell IM, et al. Differential effects of gastric bypass and banding on circulating gut hormone and leptin levels. Obesity (Silver Spring) 2006;14:1553-1561.

190. Basso N, Capoccia D, Rizzello M, et al. First-phase insulin secretion, insulin sensitivity, ghrelin, GLP-1, and PYY changes $72 \mathrm{~h}$ after sleeve gastrectomy in obese diabetic patients: the gastric hypothesis. Surg Endosc 2011;25:3540-3550.

191. Svane MS, Jorgensen NB, Bojsen-Moller KN, et al. Peptide YY and glucagon-like peptide-1 contribute to decreased food intake after Rouxen-Y gastric bypass surgery. Int J Obes (Lond)2016;40:1699-1706.

192. Rodriguez-Oroz MC, Obeso JA, Lang AE, et al. Bilateral deep brain stimulation in Parkinson's disease: a multicentre study with 4 years follow-up. Brain 2005;128:2240-2249.

193. Deuschl G, Schade-Brittinger C, Krack P, et al. A randomized trial of deep-brain stimulation for Parkinson's disease. N Engl J Med 2006;355:896-908.

194. Mayberg HS, Lozano AM, Voon V, et al. Deep brain stimulation for treatment-resistant depression. Neuron 2005;45:651660.

195. Nangunoori RK, Tomycz ND, Oh MY, Whiting DM. Deep brain stimulation for obesity: from a theoretical framework to practical application. Neural Plast 2016;2016:7971460.

196. Dupré DA, Tomycz N, Oh MY, Whiting D. Deep brain stimula- 
tion for obesity: past, present, and future targets. Neurosurg Focus 2015;38:E7.

197. Whiting DM, Tomycz ND, Bailes J, et al. Lateral hypothalamic area deep brain stimulation for refractory obesity: a pilot study with preliminary data on safety, body weight, and energy metabolism. J Neurosurg 2013;119:56-63.

198. Soto-Montenegro ML, Pascau J, Desco M. Response to deep brain stimulation in the lateral hypothalamic area in a rat model of obesity: in vivo assessment of brain glucose metabolism. Mol Imaging Biol 2014;16:830-837.

199. Hamani C, McAndrews MP, Cohn M, et al. Memory enhancement induced by hypothalamic/fornix deep brain stimulation. Ann Neurol 2008;63:119-123.

200. Melega WP, Lacan G, Gorgulho AA, Behnke EJ, De Salles AA. Hypothalamic deep brain stimulation reduces weight gain in an obesityanimal model. PLoS One 2012;7:e30672.

201. Laćan G, De Salles AA, Gorgulho AA, et al. Modulation of food intake following deep brain stimulation of the ventromedial hypothalamus in the vervet monkey. Laboratory investigation. J Neurosurg 2008;108:336342.

202. Lehmkuhle MJ, Mayes SM, Kipke DR. Unilateral neuromodulation of the ventromedial hypothalamus of the rat through deep brain stimulation. J Neural Eng 2010;7:036006.

203. Sachdev PS, Cannon E, Coyne TJ, Silburn P. Bilateral deep brain stimulation of the nucleus accumbens for comorbid obsessive compulsive disorder and Tourette's syndrome. BMJ Case Rep 2012;2012. pii:bcr2012006579.

204. Munte TF, Heinze HJ, Visser-Vandewalle V. Deep brain stimulation as a therapy for alcohol addiction. Curr Top Behav Neurosci 2013;13:709727.

205. van der Plasse G, Schrama R, van Seters SP, Vanderschuren LJ, Westenberg HG. Deep brain stimulation reveals a dissociation of consummatory and motivated behaviour in the medial and lateral nucleus accumbens shell of the rat. PLoS One 2012;7:e33455.

206. Zhang C, Wei NL, Wang Y, Wang X, Zhang JG, Zhang K. Deep brain stimulation of the nucleus accumbens shell induces anti-obesity effects in obese rats with alteration of dopamine neurotransmission. Neurosci Lett 2015;589:1-6.

207. Alhadeff AL, Rupprecht LE, Hayes MR. GLP-1 neurons in the nucleus of the solitary tract project directly to the ventral tegmental area and nucleus accumbens to control for food intake. Endocrinology 2012;153:647-658.

208. Dossat AM, Lilly N, Kay K, Williams DL. Glucagon-like peptide 1 receptors in nucleus accumbens affect food intake. J Neurosci 2011;31: 14453-14457.

209. Sills TL, Vaccarino FJ. Individual differences in the feeding response to CCKB antagonists: role of the nucleus accumbens. Peptides 1996;17:593-599.

210. Naleid AM, Grace MK, Cummings DE, Levine AS. Ghrelin induces feeding in the mesolimbic reward pathway between the ventral tegmental area and the nucleus accumbens. Peptides 2005;26:2274-2279.

211. Quarta D, Di Francesco C, Melotto S, Mangiarini L, Heidbreder C, Hedou G. Systemic administration of ghrelin increases extracellular dopamine in the shell but not the core subdivision of the nucleus accumbens. Neurochem Int 2009;54:89-94. 